\title{
Use of simulators in video laparoscopic surgery in medical training: a prospective court study with medicine academic at a university in Southern Brazil
}

\section{Uso de simuladores em cirurgia videolaparoscópica na formação médica: estudo prospectivo de coorte com acadêmicos de medicina de uma universidade no Sul do Brasil}

Júlia Tonietto Porto ${ }^{1}$ id ; Luciano Silvelra Eifler, TCBC-RS²; Lucas Pastori Steffen¹; Gabrielle Foppa Rabaioli'; Joana Michelon TOMAZZONI.

\begin{abstract}
A B S T R A C T
Introduction: the onset of minimally invasive surgery, such as laparoscopic surgery, was accompanied by an increased frequency of complications, many of which were life-threatening. With the objective of minimizing morbidity and mortality and accelerating the learning curve, video laparoscopic surgery simulators were developed to improve the psychomotor skills required for these procedures. Objective: to compare the performance of second year medical students of the Lutheran University of Brazil, in simulated videolaparoscopic surgeries performed at the Realistic Simulation Center of the Faculty of Health Sciences of Porto Alegre. Method: prospective cohort study with 16 medical students with no prior experience in video-surgery simulation. The students performed simulated exercises and were evaluated regarding Coordination, Navigation by Instrument and Time in the accomplishment of the procedures. Results: the sample consisted of $69 \%$ women and $31 \%$ men with a mean age of 23.2 years. The students obtained better results in the second simulation application. The skill in Navigation by Instrument task was the one that showed the best evolution in the studied group. The Total Time in the accomplishment of the procedures was the parameter with greater difference between the successive simulations. Conclusion: medical students presented a significant improvement in their performance with the repetition of the simulation exercises, demonstrating that the Laparoscopic Surgery Simulators are a promising tool in medical training and development of surgical skills.
\end{abstract}

Keywords: General Surgery. Simulation Training. Virtual Reality. Patient Simulation. Video-Assisted Surgery.

\section{INTRODUCTION}

s n n most medical education institutions, the study of surgery is based on traditional methods, which consist of theoretical learning about surgical techniques and practical anatomy classes on cadavers. Animal training is a teaching method that has been widely used in the past, but has been decreasing over time, often due to ethical factors $^{1,2}$. In medical residency, the development of surgical skills is based on learning dependent on a certain volume of patients, and has a high level of tolerance for possible errors ${ }^{3}$. In order to insert the student in a realistic context, surgical simulators have been increasingly used in current medical training ${ }^{1,4}$.

The introduction of minimally invasive surgery, such as laparoscopy, was accompanied by an increased frequency of complications, many with risk of death for the patient ${ }^{5}$. The fact that complications are likely to occur even with surgeons experienced in open surgery has raised concerns about the training of laparoscopic surgery. A series of highly influential medical manifestations drew the attention of the general

1 - Universidade Luterana do Brasil, Curso de Medicina - Canoas - RS - Brasil 2 - Universidade Luterana do Brasil, Serviço de Cirurgia Geral - Canoas - RS - Brasil 3 - Universidade de Caxias do Sul, Curso de Medicina - Caxias do Sul - RS - Brasil 
public to issues of surgical training. New approaches to surgical training had to be considered, and simulators, developed, all for training in a controlled environment. Surgeons and teachers got involved with computer engineers to develop new simulation technologies and to validate the transfer of simulation-based training to the operating room ${ }^{6,7}$.

During traditional open or laparoscopic surgery, the surgeon interacts directly with the patient's tissues and organs using surgical instruments. In laparoscopic robotic surgery the situation is different, the surgeon sends commands remotely to mechanical arms that then perform the movements. Becoming experienced in laparoscopic robotic surgery and in laparoscopy requires technical improvement and the appropriate use of the interface control, camera, and laparoscopic instruments. Virtual reality allows practice before operating on actual patients, avoiding risks ${ }^{6}$.

The simulation of operations in virtual reality has been used to develop the psychomotor skills necessary in laparoscopic procedures ${ }^{8}$. It is an accessible, safe and controlled way in a standardized environment that aims to increase the student's learning curve and improve their skills ${ }^{8}$. Both animated and inanimate models have been created with the intention of training students' intuitive skills outside the operating room. Inanimate forms are those whose complexity ranges from black boxes to advanced virtual technologies in video simulation ${ }^{9,10}$.

A surgical simulator consists of a computer, along with physical interfaces that are equivalent to the instruments and the procedure it represents, creating a virtual environment in which the operator can interact with the program. Most simulators have didactic resources that allow to evaluate their use according to time, manipulation and predefined errors ${ }^{11}$.

The ability to perform minimally invasive surgery depends on technical skills ${ }^{12,13}$. Therefore, the Laparoscopic Surgery Simulators (LSS) represent an innovation in medical education. Advances in realistic technologies replicate real scenarios, reproducing tasks in a structured way and with an appropriate method. This imposes great learning of skills and conduct that students will face in the future with their patients ${ }^{1}$. Although some studies have already been reported, it is important to analyze whether the literature provides sufficient information on the transfer of skills of these simulators to practice, reaching the expected level of knowledge ${ }^{14,15}$.

To observe the effects of Laparoscopic Surgery Simulators, the present study aims to compare the results of exercises performed in different stages by second year medical students at the Lutheran University of Brazil (ULBRA) and to use quantitative data to verify if there is technical skill improvement by repeating the simulated exercises. Thus, the study aims to contribute to the evaluation of this method in the formation and training of surgical skills by medical students.

\section{METHODS}

This is a prospective cohort study, approved by the ethics committee of the Lutheran University of Brazil. (CAAE: 00338918.4.0000.5349).

The sample consisted of 16 students from the fourth semester of the Medical School of the Lutheran University of Brazil (ULBRA), enrolled in the Surgical Procedures discipline. The students had no previous experience with laparoscopic surgery simulators. We excluded three students for not completing all the required tasks, leaving the total sample of 13. Each student signed an Informed Consent Form with information about the objectives of the study.

The Professor of the discipline accompanied the students to Santa Casa de Porto Alegre, at the Realistic Simulations Center of the Federal University of Sciences and Health of Porto Alegre, where the simulators used in this study are located.

The simulator available for student use is the LapSim model, developed by Surgical Science (Figure 1). It consists of an equipment with a basic skills module and a portfolio of laparoscopic procedures, with exercises ranging from basic navigation to advanced suturing. Each exercise has stages and levels of increasing difficulty. There are twelve exercises, which include: camera navigation, instrument navigation, coordination, suturing, grasping, cutting, catheter insertion, clip application, lifting and grasping, bowel manipulation, and fine dissection (Table 1).

During one day, students were instructed to individually perform two of the simulator tasks: coordination and instrument navigation. Each student 
performed both exercises twice and the results were generated by the machine's own operating system. The exercises evaluated the operators according to a series of parameters, as described in Tables 2 and 3, with $\mathrm{s}$ being the seconds, $\%$, the percentage of failures, $m$, the meters covered, $\mathrm{n}$, the number of times the instrument was seen, and $\mathrm{mm}$, the millimeters of damage caused.

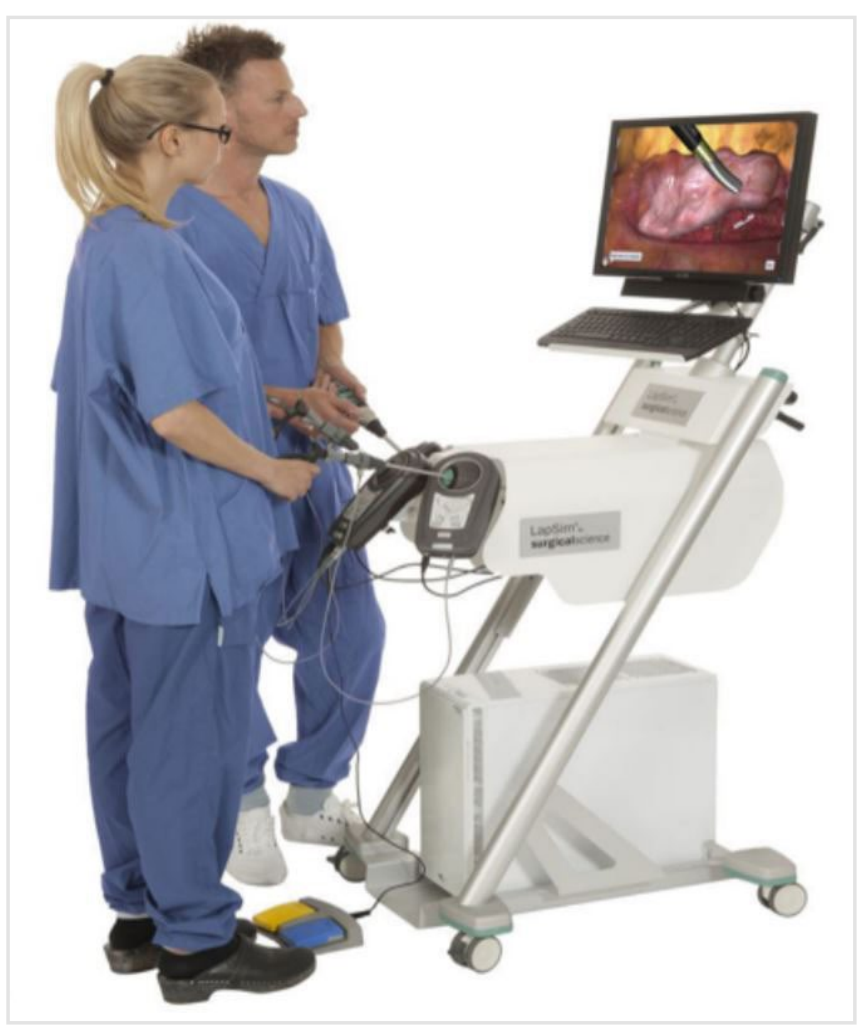

Figure 1. Laparoscopic Surgery Simulator.

After the tasks were completed, the simulator itself generated the individual results of each student, which we collected for analysis.

We performed Data analysis using the SPSS version 21.0 software, considering a significance level of $5 \%$ ( $p<0.05)$. We described quantitative variables as mean and standard deviation or median and interquartile range, depending on the data distribution. We described categorical variables by absolute and relative frequencies.

To compare the means between the two moments, we applied the Student t-test for paired samples. In case of asymmetry, we used the Wilcoxon test.
Table 1. Exercises and objectives

Exercise

Camera navigation

Instrument navigation

Coordination

Hold

Clip application Learning how to divide a vessel by applying a clip with a clip applier

Learning how to lift objects using tweezers

Lifting and Gripping

Intestinal manipulation

Learning how to measure bowel length

Practicing how to make a surgical incision in a vessel and using a catheter tweezers

Learning how to

Suture position a needle, tie a knot and tighten the thread

Learning how to

Thin dissection segments from a vascularized structure 


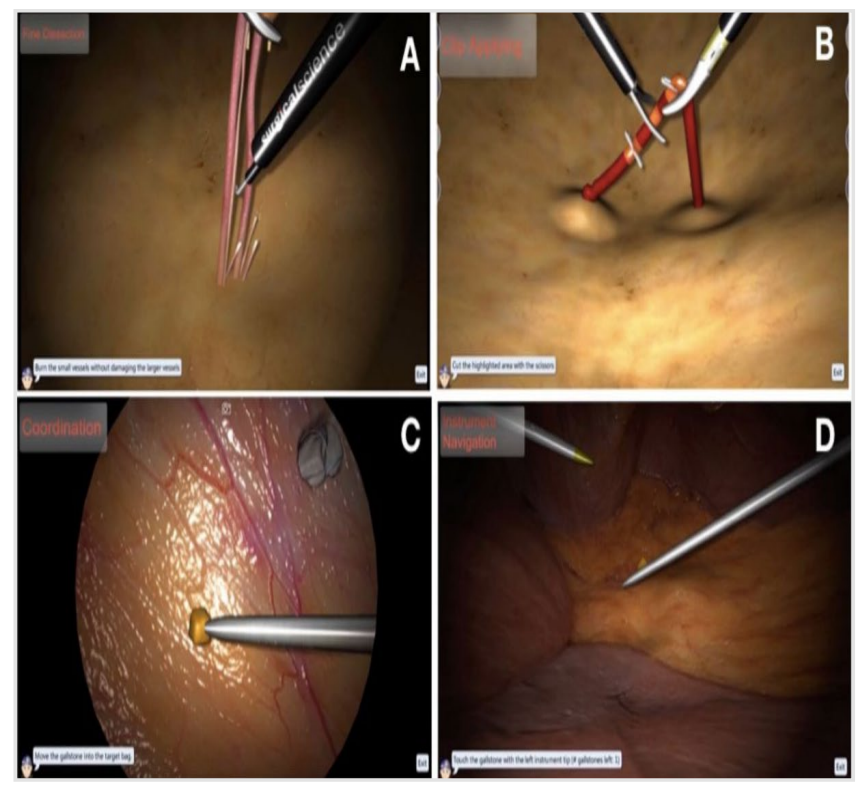

Figure 2. Simulator exercise screens. A) Fine Dissection; B) Clip Application; C) Coordination; D) Instrument Navigation.

Table 2. Parameters measured in the Coordination task.

Total time (s)

Failures (\%)

Instrument path length $(\mathrm{m})$

Angular path of the instrument (degrees)

External view of the instrument $(n)$

External view of the instrument (s)

Camera path extension $(\mathrm{m})$

Angular camera path (degrees)

Damage to tissue $(n)$

Maximum damage (mm)

\section{RESULTS}

We present the results for the final sample, composed by 13 students of the second year of the Medical School of the Lutheran University of Brazil. The study members had no previous experience in surgical simulation, being composed of $69 \%$ women and $31 \%$ men. The sample's mean age was 23.2 years, with a standard deviation of 1.5 years.
The results obtained by comparing the first and the second execution of the coordination exercise are shown in Table 4. The numbers were evaluated according to performance in the 10 parameters assessed in the task.

Table 3. Parameters measured in the Instrument Navigation task.

Left instrument time (s)

Failures with the instrument on the left (\%)

Left instrument extension (m)

Angular path of the left instrument (degrees)

Right instrument time (s)

Failure of the right instrument (\%)

Right instrument extension (m)

Angular path of the right instrument (degrees)

Damage to tissue (n)

Maximum damage $(\mathrm{mm})$

Left instrument out of sight (n)

Left instrument out of sight (s)

Right instrument out of sight ( $n$ )

Right instrument out of sight (s)

With the exception of the percentage of failures, all parameters evaluated in this task showed improved results in the second round. The total time was the only criterion displaying a statistically significant difference $(p<0.05)$.

Table 5 shows the comparison of the results obtained by the students between the first and the second rounds of instrument navigation, evaluated according to the 14 variables described. In this exercise, only the parameter angular path of the left instrument had a statistically significant result $(p<0.05)$.

\section{DISCUSSION}

The operating room is not the ideal environment for training basic skills, due to the nature of minimally 
invasive procedures, to ethical considerations, and to the repercussions on increasing surgical time ${ }^{16,17}$. Thus, new tools that facilitate training outside the operating room have been developed, such as LSS $16,18-20$.

In this study, in general, medical students showed a significant improvement in their performance with the repetition of the simulation. This shows that a student, still without experience in surgical practice, can benefit from the laparoscopic surgery simulation, learning the basics about surgical instruments and how to handle them.

One of the results with the greatest difference between the first and the second round $(p<0.05)$ was the total time parameter of the coordination exercise. This demonstrates that students have developed agility with the handling of operative instruments over the course of the repetitions, decreasing their time to perform the simulation.

Table 4. Results in the Coordination task.

\begin{tabular}{lccc}
\hline \multirow{2}{*}{ Variables } & First round & Second round & $P$ \\
\cline { 2 - 4 } & Mean \pm SD & Mean \pm SD & \\
\hline Total time $(\mathrm{s})$ & $85.8 \pm 37.9$ & $68.1 \pm 21.3$ & 0.035 \\
Failures $(\%)$ & $0 \pm 0$ & $0 \pm 0$ & - \\
Instrument path length $(\mathrm{m})$ & $1.7 \pm 0.4$ & $1.6 \pm 0.4$ & 0.432 \\
Angular path of the instrument (degrees) & $351 \pm 86.9$ & $310 \pm 79.0$ & 0.194 \\
External view of the instrument $(\mathrm{n}){ }^{*}$ & $1(0-1)$ & $0(0-1)$ & 0.190 \\
External view of the instrument $(\mathrm{s}) *$ & $0.15(0-2.1)$ & $0(0-0.1)$ & 0.285 \\
Camera path extension $(\mathrm{m})$ * & $0.36(0.17-0.45)$ & $0.20(0.13-0.40)$ & 0.382 \\
Angular camera path $($ degrees) * & $113(40.4-135)$ & $51.9(31.7-110)$ & 0.152 \\
Damage to tissue $(\mathrm{n})$ * & $3(2-4.5)$ & $2(1-3.5)$ & 0.325 \\
Maximum damage $(\mathrm{mm}) *$ & $8.9(2.3-11.3)$ & $6.1(1.7-23.2)$ & 0.807 \\
\hline
\end{tabular}

* described by median (25-75 percentiles).

Table 5. Results of the Instrument Navigation task.

\begin{tabular}{|c|c|c|c|}
\hline \multirow{2}{*}{ Variables } & First round & Second round & $\mathrm{p}$ \\
\hline & Mean \pm SD & \multicolumn{2}{|l|}{ Mean \pm SD } \\
\hline Left instrument time (s) & $42.9 \pm 29.7$ & $28.2 \pm 6.9$ & 0.074 \\
\hline Failure of the left instrument (\%) & $0 \pm 0$ & $0 \pm 0$ & - \\
\hline Left instrument extension (m) & $1.1 \pm 0.5$ & $0.8 \pm 0.1$ & 0.062 \\
\hline Angular path of the left instrument (degrees) & $241 \pm 94.7$ & $180 \pm 36.3$ & 0.013 \\
\hline Right instrument time $(s)$ & $31.3 \pm 13.7$ & $22.8 \pm 5.2$ & 0.057 \\
\hline Failure of the right instrument (\%) & $0 \pm 0$ & $0 \pm 0$ & - \\
\hline Right instrument extension (m) & $0.9 \pm 0.2$ & $0.8 \pm 0.2$ & 0.252 \\
\hline Angular path of the right instrument (degrees) & $185 \pm 69.4$ & $147 \pm 30.6$ & 0.077 \\
\hline Damage to tissue $(n) *$ & $1(0-2)$ & $1(0-1)$ & 0.602 \\
\hline Maximum damage $(\mathrm{mm})$ * & $1.3(0-9.7)$ & $0.9(0-6.3)$ & 0.583 \\
\hline Left instrument out of sight $(n)$ * & $0(0-0)$ & $0(0-0)$ & 0.317 \\
\hline Left instrument out of sight $(\mathrm{s})$ * & $0(0-0)$ & $0(0-0)$ & 0.317 \\
\hline Right instrument out of sight $(n)$ * & $0(0-0)$ & $0(0-0)$ & 1.000 \\
\hline Right instrument out of sight $(\mathrm{s})$ * & $0(0-0)$ & $0(0-0)$ & 1.000 \\
\hline
\end{tabular}


Parameters that evaluated the percentage of failures and the instruments' field of view, both on the right and on the left, showed no difference in results with repetition. That's because all the students of this study showed good performance from the first round in these parameters. We observed that the instrument navigation exercise led to a greater development of skills than the coordination exercise, which can be verified by the results acquired in both tasks. The numbers in all parameters had a greater difference between the first and the second rounds in this exercise.

The other parameters evaluated, although showing improvement in results with repetition, were not statistically significant, probably because of the small sample in this study. In addition, the number of repetitions in the exercises may not have been sufficient to render a more expressive learning curve. The trend is the progressive improvement in the ability to perform tasks as the repetition increases in the simulated exercises.

The present study has as a limitation the absence of sample size calculation, which would guarantee greater strength in the conclusions presented.

The insertion of laparoscopic simulation in the curriculum of educational institutions requires a lot of effort, time and money ${ }^{21,22}$. Studies show that acquiring proficiency in LSS requires approximately 2.5 hours of supervised training and 5 hours of unsupervised training in the various tasks provided by the machines ${ }^{22}$. This is relatively short time to get undergraduates used to laparoscopic procedures and materials.

The contact with surgical simulators at the beginning of graduation provides students with the learning of basic concepts in laparoscopic surgery and the acquisition of psychomotor and cognitive skills, even before entering the operating room, which represents a reduction in the time spent on the learning curve for future surgeons and for patients.

\section{CONCLUSION}

The use of high-fidelity simulators with virtual reality technology in the training of laparoscopic surgery is a new method in our country and is being incorporated into the curriculum of medical schools that have advanced simulation laboratories. The growing concern with patient safety, combined with the incorporation of new technologies and the search for more efficient teaching methods, make Laparoscopic Surgery simulators a fundamental tool in undergraduate and residency medical training in surgery.

In the present study, the use of simulators proved to be an extremely effective method, reducing the time of the learning curve and improving the performance of medical students in carrying out the proposed procedures.

The results of this study indicate that the use of this teaching method can bring great benefit to medical education and contribute to the training of future surgeons more quickly and safely.

\section{R E S U M O}

Introdução: o início da cirurgia minimamente invasiva, como a cirurgia laparoscópica, foi acompanhado por frequência aumentada de complicações, muitas com risco de morte. Com o objetivo de minimizar a morbidade e mortalidade e acelerar a curva de aprendizado, foram desenvolvidos simuladores de cirurgia videolaparoscópica para aprimoramento de habilidades psicomotoras necessárias nestes procedimentos. Objetivo: comparar o desempenho de acadêmicos do segundo ano de medicina da Universidade Luterana do Brasil, na realização de cirurgias videolaparoscópicas simuladas, feitas no Centro de Simulação Realística da Faculdade de Ciências da Saúde de Porto Alegre. Método: estudo prospectivo de coorte com 16 alunos de Medicina sem experiência prévia em simulação de vídeocirurgia. Os alunos realizaram exercícios simulados e foram avaliados quanto a Coordenação, Navegação por Instrumento e Tempo na Realização dos Procedimentos. Resultados: a amostra foi composta por 69\% de mulheres e 31\% de homens com média de idade de 23,2 anos. Os acadêmicos obtiveram melhora dos resultados na segunda aplicação da simulação. A habilidade na tarefa Navegação por Instrumento foi a que teve melhor evolução no grupo de alunos avaliados. O Tempo Total na realização dos procedimentos foi o parâmetro com maior diferença entre as simulações sucessivas. Conclusão: os acadêmicos de Medicina apresentaram expressiva melhora de desempenhos com a repetição dos exercícios de simulação, demonstrando que os Simuladores de Cirurgia Videolaparoscópica são ferramentas promissoras no treinamento de habilidades cirúrgicas na formação médica.

Palavras chave: Cirurgia Geral. Treinamento por Simulação. Realidade Virtual. Treinamento por simulação de Alta Fidelidade. Cirurgia Videoassistida. 


\section{REFERENCES}

1. Lemos FMFC. Aquisição de habilidades em cirurgia videolaparoscópica por residentes em cirurgia geral após treinamento em simulador de alta fidelidade [dissertação]. Palmas (TO): Universidade Federal do Tocantins; 2016.

2. Ahlberg G, Enochsson L, Gallager AG, Hedman L, Hogman C, McClusky 3rd DA, et al. Proficiencybased virtual reality training significantly reduces the error rate for residents during their first 10 laparoscopic cholecystectomies. Am J Surg. 2014;193(6):797-804.

3. Munro MG. Surgical simulation: where have we come from? Where are we now? Where are we going? J Minim Invasive Gynecol. 2012;19(3):27283.

4. Buzink S, Soltes M, Radonak J, Fingerhut A, Hanna G, Jakimowicz J. Laparoscopic Surgical Skills programme: preliminary evaluation of Grade I Level 1 courses by trainees. Wideochir Inne Tech Maloinwazyjne. 2012;7(3):188-92.

5. Gallagher AG, O' Sullivan GC. Fundamentals of surgical simulation: principles and practice. London: Springer; 2012.

6. Moglia A, Sinceri S, Ferrari V, Ferrari M, Mosca $F$, Morelli L. Proficiency based training of medical students using virtual simulators for laparoscopy and robot assisted surgery: results of a pilot study. Updates Surg. 2018;70(3):401-5.

7. Rehman S, Raza SJ, Stegemann AP, Zeeck K, Din R, Llewellyn $A$, et al. Simulation-based robot-assisted surgical training: a health economic evaluation. Int J Surg. 2013;11(9):841-6.

8. Huber $T$, Paschold $M$, Hansen $C$, Wunderling $T$, Lang $H$, Kneist W. New dimensions in surgical training: immersive virtual reality laparoscopic simulation exhilarates surgical staff. Surg Endosc. 2017;31(11):4472-7.

9. Ferreira Filho F, Moura Júnior LG, Rocha HAL, Rocha SGMO, Ferreira LFP, Ferreira AFP. Abdominal cavity simulator for skill progression in videolaparoscopic sutures in Brazil. Acta Cir Bras. 2018;33(1):75-85.

10. Våpenstad $C$, Hofstad EF, Bø LE, Kuhry E, Johnsen $G$, Marvik R, et al. Lack of transfer of skills after virtual reality simulator training with haptic feedback. Minim Invasive Ther Allied Technol. 2017;26(6):346-54.

11. Bashankaev B, Baido S, Wexner SD. Review of available methods of simulation training to facilitate surgical education. Surg Endosc. 2015;25(1):2835.

12. Fu S, Liu X, Zhou L, Zhou M, Wang L. Applied research on laparoscopic simulator in the resident surgical laparoscopic operation technical training. Indian J Surg. 2017;79(4):288-93.

13. Gallagher AG, Ritter EM, Champion H, Higgins G, Fried MP, Moses $G$, et al. Virtual reality simulation for the operating room: proficiency-based training as a paradigm shift in surgical skills training. Ann Surg. 2005;241(2):364-72.

14. Moglia A, Ferrari V, Morelli L, Ferrari M, Mosca F, Cuschierri A. A systematic review of virtual reality simulators for robot-assisted surgery. Eur Urol. 2016;69(6):1065-80.

15. Goh AC, Goldfarb DW, Sander JC, Miles BJ, Dunkin BK. Global evaluative assessment of robotic skills: validation of a clinical assessment tool to measure robotic surgical skills. J Urol. 2012;187(1):247-52.

16. Milburn JA, Khera G, Hornby ST, Malone PSC, Fitzgerald JEF. Introduction, availability and role of simulation in surgical education and training: review of current evidence and recommendations from the Association of Surgeons in Training [editorial]. Int J Surg. 2012;10(8):393-8.

17. Våpenstad C, Hofstad EF, Bø LE, Chmarra MK, Kuhry $E$, Johnsen $G$, et al. Limitations of haptic feedback devices on construct validity of the LapSim ${ }^{\circledR}$ virtual reality simulator. Surg Endosc. 2013;27(4):138696.

18. Sadideen H, Hamaoui K, Saadeddin M, Kneebone R. Simulators and the simulation environment: getting the balance right in simulation-based surgical education. Int J Surg. 2012;10(9):458-62.

19. Vassiliou MC, Feldman LS, Andrew CG, Bergman $S$, Leffondré K, Stanbridge D, et al. A global assessment tool for evaluation of intraoperative laparoscopic skills. Am J Surg. 2015;190(1):10713.

20. Liu A, Tendick F, Cleary K, Kaufmann C. A survey of 
surgical simulation: applications, technology, and education. Presence. 2003;12(6):599-614.

21. Bric J, Connolly M, Kastenmeier A, Goldblatt $M$, Gould JC. Proficiency training on a virtual reality robotic surgical skills curriculum. Surg Endosc. 2014:28(12):3343-8.

Received in: 08/05/2020

Accepted for publication: 06/07/2020

Conflict of interest: no.

Funding source: none.
22. Sroka G, Feldman LS, Vassiliou MC, Kaneva PA, Fayez R, Fried GM. Fundamentals of laparoscopic surgery simulator training to proficiency improves laparoscopic performance in the operating room - a randomized controlled trial. Am J Surg. 2010;199(1):115-20.

\section{Mailing address:}

Júlia Tonietto Porto

E-mail: jutporto@gmail.com

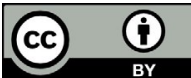

